Author has nothing to disclose with regard to commercial support.
3. Barberini L, Montisci A, Cerri A, Miceli A. Commentary: acute kidney injury after cardiac surgery: is the "-omics" way the right way? J Thorac Cardiovasc Surg. March 30, 2019 [Epub ahead of print].

4. Hoff U, Bubalo G, Fechner M, Blum M, Zhu Y, Pohlmann A, et al. A synthetic epoxyeicosatrienoic acid analog prevents the initiation of ischemic acute kidney injury. Acta Physiol (Oxf). 2019:e13297.

5. Jin J, Chang SC, Shen B, Xu J, Jiang W, Wang Y, et al. Usefulness of high estimated pulmonary artery systolic pressure to predict acute kidney injury after cardiac valve operations. Am J Cardiol. 2019;123:440-5.

6. Shi J, Wu G, Zou X, Jiang K. Enteral baicalin, a flavone glycoside, reduces indicators of cardiac surgery-associated acute kidney injury in rats. Cardiorenal Med. 2019;9:31-40.

7. He SJ, Liu Q, Li HQ, Tian F, Chen SY, Weng JX. Role of statins in preventing cardiac surgery-associated acute kidney injury: an updated meta-analysis of randomized controlled trials. Ther Clin Risk Manag. 2018;14:475-82.

8. Cortes AL, Gonsalez SR, Rioja LS, Oliveira SSC, Santos ALS, Prieto MC, et al. Protective outcomes of low-dose doxycycline on renal function of Wistar rats subjected to acute ischemia/reperfusion injury. Biochim Biophys Acta Mol Basis Dis. 2018;1864:102-14.

9. Leow EH, Chan YH, Ng YH, Lim JKB, Nakao M, Lee JH. Prevention of acute kidney injury in children undergoing cardiac surgery: a narrative review. World J Pediatr Congenit Heart Surg. 2018;9:79-90.

10. Waskowski J, Pfortmueller CA, Erdoes G, Buehlmann R, Messmer AS, Lueldi MM, et al. Mannitol for the prevention of peri-operative acute kidney injury: a systematic review. Eur J Vasc Surg. 2019;58:130-40.

11. Jahnukainen T, Keski-Nisula J, Tainio J, Valkonen H, Pätilä T, Jalanko H, et al. Efficacy of corticosteroids in prevention of acute kidney injury in neonates undergoing cardiac surgery. A randomized controlled trial. Acta Anaesthesiol Scand. April 17, 2018 [Epub ahead of print].

12. Mei M, Zhao HW, Pan QG, Pu YM, Tang MZ, Shen BB. Efficacy of $\mathrm{N}$-acetylcysteine in preventing acute kidney injury after cardiac surgery: a meta-analysis study. J Investig Surg. 2018;31:14-23.

13. Swaminathan M, Stafford-Smith M, Chertow GM, Warnock DG, Paragamian V, Brenner RM, et al. Allogeneic mesenchymal stem cells for treatment of AKI after cardiac surgery. J Am Soc Nephol. 2018;29:260-7.

14. Bellos I, Iliopoulos DC, Perrea DN. Pharmacological interventions for the prevention of acute kidney injury after pediatric cardiac surgery: a network meta-analysis. Clin Exper Nephrol. 2019;23:782-91.

15. Li X, Zhang C, Dai D, Liu H, Ge S. Efficacy of dexmedetomidine in prevention of junctional ectopic tachycardia and acute kidney injury after pediatric cardiac surgery: a meta-analysis. Congenit Heart Dis. 2018;13:799-807.

16. Liu Y, Sheng B, Wang S, Lu F, Zhen J, Chen W. Dexmedetomidine prevents acute kidney injury after adult cardiac surgery: a meta-analysis of randomized controlled trials. BMC Anaesth. 2018:18:7.

17. Aujla H, Kumar T, Wozniak M, Dott W, Sullo N, Joel-David L, et al. Effect of sildenafil (Revatio) on postcardiac surgery acute kidney injury: a randomised, placebo-controlled clinical trial: the REVAKI-2 trial protocol. Open Heart. 2018;5:e000838.

18. Litton E, Bass F, Delaney A, Hills G, Marasco S, McGuinness S, et al. Six-month outcomes after high-risk coronary artery bypass graft surgery and preoperative intra-aortic balloon counterpulsation use: an inception cohort study. J Cardiovasc Thorac Vasc Anesth. 2018;32:2067-73.

19. Qureshi SH, Patel NN, Murphy GJ. Vascular endothelial cell changes in postcardiac surgery acute kidney injury. Am J Physiol Renal Physiol. 2018;314:F726-35.

20. Song JW, Lee WK, Lee S, Shim JK, Kim HJ, Kwak YL. Remote ischaemic conditioning for prevention of acute kidney injury after valvular heart surgery: a randomised controlled trial. Br J Anaesth. 2018;121:1034-40.

21. Zhou C, Bulluck H, Fang N, Li L, Hausenloy DJ. Age and surgical complexity impact on renoprotection by remote ischemic preconditioning during adult cardiac surgery: a meta analysis. Scientific Rep. 2017;7:215.

22. He X, Wang Y, Cong H, Lu C, Wu J. Impact of optimal medical therapy at discharge on one-year direct medical costs in patients with acute coronary syndromes: a retrospective, observational database analysis in China. Clin Ther. 2019;41:456-65.e452.
23. Jahangirifard A, Ahmadi ZH, Naghashzadeh F, Sharif-Kashani B, RashidFarokhi F, Afshar A, et al. Prophylactic fibrinogen decreases postoperative bleeding but not acute kidney injury in patients undergoing heart transplantation. Clin Appl Thromb Hemost. 2018;24:998-1004.

24. Leistner DM, Munch C, Steiner J, Erbay A, Riedel M, Gebhard C, al set. Impact of acute kidney injury in elderly ( $\geq 80$ years) patients undergoing percutaneous coronary intervention. J Interv Cardiol. 2018;31:792-8.

25. Liu W, Xi Z, Gu C, Dong R, Al Helal J, Yan Z. Impact of major bleeding on the risk of acute kidney injury in patients undergoing off-pump coronary artery bypass grafting. J Thorac Dis. 2018;10:3381-9.

https://doi.org/10.1016/j.jtcvs.2019.06.012

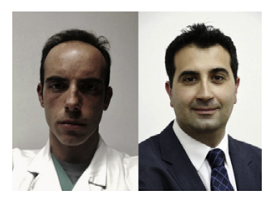

REPLY FROM THE AUTHORS: CARDIAC SURGERYASSOCIATED ACUTE KIDNEY INJURY-

\section{FINDING THE GUNPOWDER}

\section{Reply to the Editor:}

We are grateful to Ortega-Loubon and colleagues for their response. Cardiac surgery-associated acute kidney injury is a complex issue requiring a multifaceted approach, including prevention and interventional measures. In this regard, we would like to point out some aspects of the problem expressed in our commentary ${ }^{1}$ on their study ${ }^{2}$ :

1. The concept of "limited clinical significance" was directed to all monitoring systems that, although registering an event, do not allow a time window to undertake a preventive or interventional measure. We understand that "an opportune recognition is crucial for an optimal treatment"; at the same time, however, we learned from research on brain saturation monitoring that the identification of the sentinel event do not translate into effective therapeutic measures. ${ }^{3,4}$

2. In cardiac surgery-associated acute kidney injury, prevention and intervention are equally important. Many factors involved in its pathogenesis are not or marginally modifiable (age, preoperative risk profile, preexistent chronic kidney disease, cardiopulmonary bypass time). Moreover, therapeutic measures able to revert or arrest the progression of established damage are limited.

3. The extension of the monitoring period of kidney regional saturation beyond the intraoperative phase represents the most important characteristic of the study, as OrtegaLoubon and colleagues ${ }^{2}$ demonstrated that renal damage can take place even in the absence of overt systemic hypoperfusion, prompting strict surveillance.

Keeping with the metaphor in our commentary, we are still lacking gunpowder against cardiac surgery-associated acute kidney injury.

Andrea Montisci, $M D^{a, b}$ Antonio Miceli, $M D, P h D^{c}$

Departments of ${ }^{a}$ Anesthesia and Intensive Care and ${ }^{c}$ Minimally Invasive Cardiac Surgery 
Authors have nothing to disclose with regard to commercial support.

Cardiothoracic Center Istituto Clinico Sant'Ambrogio

Milan, Italy

${ }^{b}$ Cardiac Surgery University of Milan Milan, Italy

\section{References}

1. Montisci A, Travaglini S, Miceli A. Commentary: the lack of a magic bullet. J Thorac Cardiovasc Surg. 2019;157:2352-3.

2. Ortega-Loubon C, Fernández-Molina M, Fierro I, Jorge-Monjas P, Carrascal Y, Gómez-Herreras JI, et al. Postoperative kidney oxygen saturation as a novel marker for acute kidney injury after adult cardiac surgery. $J$ Thorac Cardiovasc Surg. 2019;157:2340-51.e3.

3. Arrowsmith JE, Ganugapenta MSSR. Intraoperative brain monitoring in cardiac surgery. In: Bonser RS, Pagano D, Haverick A, eds. Brain Protection in Cardiac Surgery. London: Springer-Verlag; 2011:83-111.

4. Yu Y, Zhang K, Zhang L, Zong H, Meng L, Han R. Cerebral near-infrared spectroscopy (NIRS) for perioperative monitoring of brain oxygenation in children and adults. Cochrane Database Syst Rev. 2018;1:CD010947.

https://doi.org/10.1016/j.jtcvs.2019.07.013 